\title{
Community-Based Economics Empowerment and Development in Maluku Province
}

\author{
Gerrit M. Pentury ${ }^{1}$, Stellamaris Metekohy ${ }^{2}$, Priscillia Picauly ${ }^{3}$ \\ ${ }_{1,2,3}$ (Faculty of Economics, Pattimura University, Indonesia)
}

\begin{abstract}
In the current era of autonomization, every province, district / city as a unit of government administration, seeks to find the right strategy to improve the welfare of its people. Underdeveloped regions are certainly struggling to find inspiration to determine the right strategy to overcome their condition or to alleviate poverty. The purpose of this study is to assess the existence of empowerment groups as the basis for the establishment of policies and work programs for empowerment groups, especially the community-based economy and development for strengthening the institution. This study is a qualitative in nature that includes explorative, community development, participatory methods, facility methods, and survey methods. The results show that there is no financial support and assistance from the government / banking / other institutions. Not open to new ideas and technological developments. To support the economic activities of the community, they need to double the support of the availability of land / sea transportation routes, ports, markets, and other public facilities. The effectiveness of community-based economic empowerment is not optimal yet. This can be seen from the results of the study where many community-based economic programs are innacurate to community needs, ineffective, and not sustainable. The main potential economic sector to be developed is fisheries. If the fishery sector can run sustainably, it will appear other sectors of fisheries supporting business such as seaweed processing industry that will have an impact on the demand for products characterized by Maluku.
\end{abstract}

Keywords : Empowerment, Economic Development, Community Based, Maluku Province.

\section{Introduction}

Background: Structurally, poverty is still common among us, among others, marked by social inequality. This happens due to the condition of there is a group of people who are not able to meet their needs and do not have access to key resources, and on the other hand there is a group of elites who master a variety of key resources redundantly.

However, the government does did a number of efforts to overcome this problem. Unfortunately, poverty reduction programs that are designed and offered often overlap, not even in accordance with the aspirations and needs of the local people.

Various national strategies have been formulated in the form of a national program, and have been implemented to change the status or position of "underdeveloped" region to developed region. Regional development is largely determined by the potential possessed by a region, so that the policy made by the local government should refer to the potential areas that are likely to be developed. In general, each region has potential that can be developed as a driver of regional economic growth. The potential in question is mostly located in rural areas. Potential include 1) the development of horticultural crops; 2) development of plantation crops; 3) development of fishery business; 4) development of livestock business; 5) development of mining business; 6) industrial sector development; And 7) tourism potential.

Th development sectors have been fully analyzed since the analyzis is needed to determine the policies of regional government so that it able to formulate suitable and effective policies. Since the study of institutional aspects at the district / city level as the basis for the determination of policies and work programs for institutional strengthening, especially the community-based economy is considered as insufficient, it is deemed necessary to do research. There are several districts / municipalities in Maluku Province which are the study areas in this study. Maluku Province is an archipelago province whose territory is largely coastal, in the approach taken for coastal development should be based on five pillars..

Problem Identification: Limited and disfunctioning community-based economic empowerment and development and its existence in forming Maluku's institutions.

\section{Theoretical Study}

Community-based development that promotes community participation is absolutely necessary since it is an integral part of the efforts to improve the access to key resources, and also ultimately accelerating social mobility leading to the improvement of social structures. The basic concept is to invite and populate the 
community as subject and policy makers through a comprehensive approach of social, economic and environmental (Mardikanto T, 2010).

Although comprehensive human development through social, economic and environmental sectors still remains the foundation for poverty alleviation, environmental development is given special emphasis as a motor to create a conducive environment and is expected to bring positive economic and social impacts.

The form of community-based development / empowerment is through the fostering of the economic institutions of the community in disadvantaged areas, such as koperasi, small and medium enterprises and other micro enterprises, to be developed in order to create a strong economic structure supported by a robust people economy (Krisna Wijaya, 2002).

The first of the Five Pillars of coastal area development is, strengthening the social and economic capacity of coastal communities themselves. Second, the development of local resource-based entrepreneurship. Third, the commitment of the central government and the local government towards the realization of coastal communities to be empowered and independent. Fourth, synergy and cooperation by encouraging private sector participation in a profitable partnership. Fifth, sustainable management of natural resources. At the practical level of the economy, the empowerment of coastal communities is based on local community-based business development efforts, managed participatively for the benefit of all parties. In order for the system to run, it needs support from other stakeholders from the government and other parties / private (Azis, H. Moh Ali, 2005).

Faced with these conditions, the development in the coastal and underdeveloped areas, especially in Maluku Province can be pursued through the role of Institutional Economy, namely by encouraging the participation of the people of Maluku in developing the region especially in efforts to alleviate poverty. Community-based economy institutional development is an alternative development in Maluku Province in the context of disadvantaged areas, which should be implemented simultaneously in a comprehensive framework, such as education, community empowerment, social development, infrastructure provision and so on.

\section{Research Method}

The following methods used in preparing the Model of Empowerment and Economic Development; 1). Explorative: Basically the activity of this stage is an interpretation of data on observation results in the field and literature review of agencies using descriptive and explorative analysis techniques. Explorative analysis techniques used in researching typology or the classification of the problems encountered in the activities in the region. The analytical work with this methodology is not an absolute undertaking in this study. These models are alternative methods that may be used if data and information have been obtained. It is possible that in the analysis of this research will be used a combination of theoretical methods and the results of field studies may even find another model that is considered more appropriate to represent the existing conditions. 2). Community Development: This method is commonly used for a direct community approach. This method is also very dynamic because it will be tailored to the needs and conditions of the local community. For example, for people who are underdeveloped, most of the population is fishermen, it will be reviewed what problems occur when the population undergoes their principal activities. Then will be reviewed ways or tools that can be used to solve problems or minimize the challenge. The means of settlement will be reviewed from all aspects including financing, which of course with the main objective to be able to empower the underdeveloped community. Such method or methods must also be able to be done by the local community without having to cause a great dependence on resources, especially human resources coming from outside the region. 3). Participatory Methods: In conducting this study, participative methods, interviews, questioners, and conduct direct observation will be used in the field. In order to obtain input during the initial concept, until the completion of the final result will be dissemination and dissemination strategy formulation through several steps, such as the implementation of the discussion / dialogue forum. The discussion forum or dialogue is conducted formally and informally with relevant Local Government, stakeholders, Experts, practitioners and other relevant institutions / institutions, with the aim of getting input more fully in order to prepare the formulation of the final plan concept.

\section{Result Of The Research}

General Condition of Maluku Region: The economic condition of Maluku shows a sign of recovery, as can be seen from the GRDP according to the rising expenses and the continued positive economic growth.

\section{Role Analysis of Community-Based Economic Empowerment and Development}

Based on the results of data analysis that has been done through this research activity, it is known that, in general, the empowerment groups still have not received many facilities from various institutions of business partners. A lot of capital assistance is provided by the Social Services for the joint business group (KUBE). In addition, capital assistance has also been provided by the Department of Agriculture and Fisheries, especially for groups of people engaged in fisheries and processing of fishery products which amounted to up to 100 million rupiah per business group. In addition to capital grants, the Agriculture and Fisheries Department has 
also provided assistance and facilitation to people who want to apply for loans to banks. In addition, the Agriculture and Fisheries Department also provides assistance to community business groups in the form of equipment assistance. For entrepreneurship training activities have also been routinely implemented by the Department of Cooperatives and SMEs and technical guidance assistance has also been implemented by the Department of Industry and Commerce. However, the identification of the provision of assistance from these institutions to the community, factually still not evenly distributed.

Providing assistance to the empowerment group is a form of coaching and capital is part of the process of strengthening the people's economy. However, once again the spread is still not evenly distributed because those who have received assistance either capital or other forms of assistance consist of only small portion. Other forms of assistance received by the people who have received assistance are equipment assistance. However, the number is still not much that only $5 \%$ of the total respondents. Associated with capital resources for businesses run by the community can be seen in table 1 below:

Table 1. Source of Capital of the Empowerment Group

\begin{tabular}{|c|l|c|c|}
\hline No. & \multicolumn{1}{|c|}{ Source of Capital } & Number & Percentage (\%) \\
\hline 1 & Personal & 59 & 57,8 \\
\hline 2 & Bank & 6 & 5,90 \\
\hline 3 & Family & 15 & 14,7 \\
\hline 4 & Local Government & 2 & 2,00 \\
\hline 5 & Non-Bank Financial Institution & 5 & 4,90 \\
\hline 6 & State-owned Enterprise & 1 & 1,00 \\
\hline 7 & individual To t a l & 14 & 13,7 \\
\hline
\end{tabular}

Source: Primary Data.

Based on the above table, it can be seen that the majority of sources of capital of the empowerment group is sourced from own capital is $57.8 \%$, while the sourced from the banking sector only ranges from $5.90 \%$, from family $14.7 \%$, from local government $2 \%$, from individual $13.7 \%$ and other sources (non-bank financial institutions and SOEs) $5.90 \%$. This illustrates that the role of banks in business development already exists, although still quite low, so that the empowerment group is difficult to develop their business activities. In terms of meeting the needs of raw materials and equipment required approximately $87 \%$ are met locally and $13 \%$ from other regions.

\section{Description of Social Condition and Regional Infrastructure}

The acceleration of development in various sectors without excluding the development of economic sectors in all regions is in need of adequate infrastructure support. The condition is also one of the conditions for the smooth economic development of a region. Infrastructure support available to support economic development especially land transportation, terminals, ports, markets and other facilities such as lighting sources, fuel sources and clean water facilities is urgently needed.

\section{Effectiveness Analysis of Economic Empowerment}

Table 2 below describes the existence of local community empowerment programs implemented by local governments in order to promote the local community's economy. From 102 respondents, it is seen that most of respondents $(61,7 \%)$ stated that there is no local community empowerment program, $23,5 \%$ of respondents stated that rarely there is activity and the rest only $14,7 \%$ which often have empowerment program. The data can show two possibilities that happened, firstly not exactly target of empowerment program activity for local community, because from result of visit to related institution like Department of Agriculture and Fishery, Department of Cooperation, Industry and Trade Office seen that each service every year already have And run their work programs in order to provide knowledge and skills to the community. Secondly, the local people lack understanding of community empowerment programs that have been implemented by the relevant agencies.

Table 2. Existence of Local Government Empowerment Program

\begin{tabular}{|c|cc|c|c|}
\hline No. & Program existence & Number & Percentage (\%) \\
\hline 1 & Never & 63 & 61,7 \\
\hline 2 & rarely & 24 & 23,5 \\
\hline 3 & often & 15 & 14,7 \\
\hline \multicolumn{2}{|c|}{ Tot a l } & $\mathbf{1 0 2}$ & $\mathbf{1 0 0}$ \\
\hline
\end{tabular}

Source: Primary Data, 2015 
Next is the response of respondents about the role of local government empowerment programs for local human resources in encouraging economic development in Alalak and surrounding areas. Of the 102 respondents, most of the respondents (65.7\%) stated that they were not right on target, while only $22.5 \%$ said they were right on target and $11.8 \%$ were very targeted.

Table 3 is in line with table 2 above, indicating that the empowerment program that has been run by the local government is not well targeted and still not in accordance with what is expected by the empowerment group.

Table 3. Acceleration of Community Empowerment

Source: Primary Data, 2015

\begin{tabular}{|c|l|c|c|}
\hline No. & \multicolumn{1}{|c|}{ Accuracy Goals } & number & percentage (\%) \\
\hline 1 & Very Right Goal & 12 & 11,8 \\
\hline 2 & Right Goal & 23 & 22,5 \\
\hline 3 & Inappropriate Goal & 67 & 65,7 \\
\hline \multicolumn{2}{|r|}{ T o t a I } & $\mathbf{1 0 2}$ & $\mathbf{1 0 0}$ \\
\hline
\end{tabular}

\section{Business / Economic Sector}

Recently, Economic sectors in Maluku began to ogled by the community to conduct economic activities in the form of entrepreneurship by establishing economic institutions. To be a successful entrepreneur and not easy to do. From the data above, it shows that in Maluku, half of the business done in the industry sector, most of which organized by business entities in the form of CV, UD, and PT. Sector / fishery business, and livestock sector / business also received significant attention from economic institutions in Maluku. Both sectors / economic enterprises are also managed by a business entity in the form of joint business group.

The results of this study provide a very clear picture that the industrial sector and the agricultural sector (fishery sub-sector and livestock sub-sector) contribute substantially to the growth of economic institutions in Maluku, compared to other economic sectors / sectors (other sectors In GRDP).

\section{Work Force}

The growth of institutional / economic empowerment groups in Maluku should be directed to accomodate a larger workforce. The government needs to pay more attention to the primary sector because this sector accomodate quite a lot of labor. Meanwhile, the development of this sector tends to decrease, followed by the increase of secondary sector and tertiary sector which relatively little need labor. Increased public awareness is needed, especially economic empowerment groups in Maluku to remain proud to work in the agricultural sector because this sector is worth maintaining.

The problem of supply-demand in employment in Maluku deserves the attention of all parties. The surplus of labor can be overcome by the investment of productive sectors either from the government or even addressed by the private sector in this case the economic institutions. Of course this also must be coupled with human capital investment both from the community as the owner of labor factors, business actors and government. Thus, it will provide a large enough stimulus for the increase in income and employment.

The demands of the role of all parties, both communities, business actors and governments to create a conducive political and security environment for investment in Maluku so that in turn will also provide wider opportunities for workers to conduct business activities. The development and deployment of manpower in Maluku based on the existing empowerment groups can be seen in Figure 1. Below

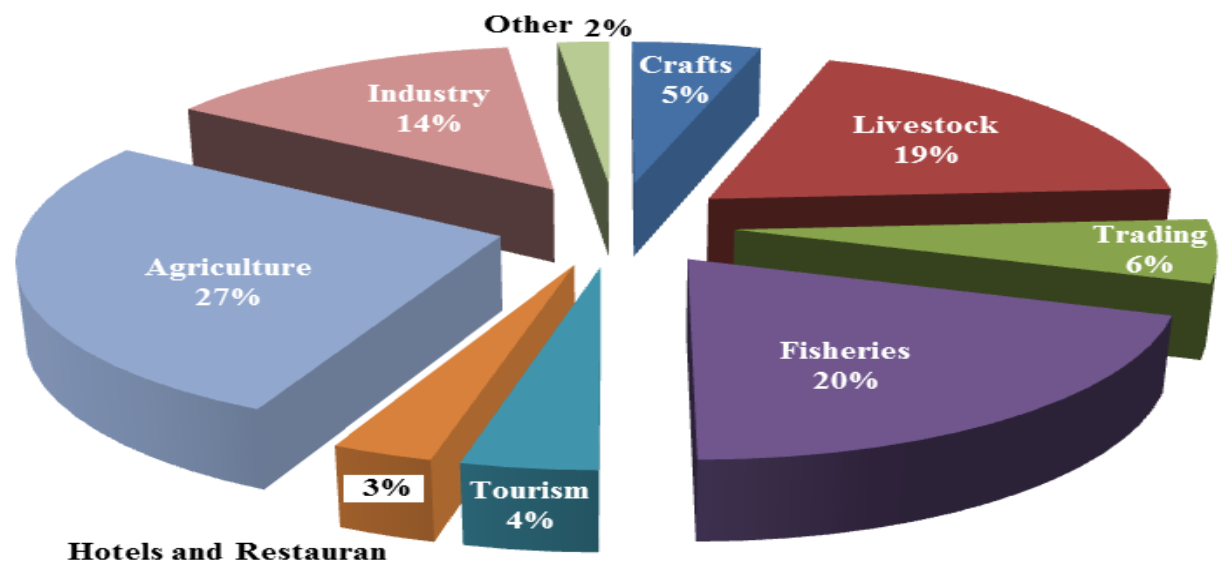

Figure 1. Work Force by Empowerment Group 
Based on Figure 1. above, it can be seen that the absorption of labor in the economic empowerment group in Maluku spread to variosu business fields. 14\% of the business sector, $27 \%$ of agricultural business, hotel and restaurant business $3 \%$, tourism business $4 \%$, other businesses $2 \%$, fisheries business $20 \%$, trading $6 \%$. The livestock business sector is $19 \%$, the craft sector is $5 \%$.

Labor is scattered in all forms of business types / sectors and is a variation of all forms of empowerment. The form of business entity is also spread in several cities / sub-districts in Maluku. The results of the study show that the characteristics of economic empowerment groups greatly affect the number of workers in relation to the application of minimum wage regulations at the enterprise level. In general, firms in the capital-intensive sector pay higher wages, and therefore show the application of regulations of higher minimum wage than firms in the labor-intensive sector. Company size is also a determining factor in the adoption of minimum wage regulations. Generally, larger companies will be able to pay higher wages, and therefore the application of minimum wage rules is better than small companies. Foreign capital companies also generally pay higher wages and apply minimum wage regulations more effectively than domestic firms. Meanwhile, firms that sell their products to the export market pay higher average wages and apply minimum wage regulations better than firms that only target the domestic market.

\section{Investation}

To improve the investment climate, cooperation between the private sector and government and intergovernmental coordination is needed. In addition, the quality of policies and institutional capacity needs to be improved. Non-economic issues such as corruption and political competition ahead of the election should be anticipated so that there will be no decreasing confidence among the investors.

Another challenge faced by entrepreneurs in Maluku in investing is how Permenakertrans No. 13 of 2012 concerning to provincial minimum wage (UMP), can be implemented appropriately. There are several variables: productivity, economic growth, labor market conditions, and the most inadequate effort, the welfare of workers / workers, and others. Even inflation and housing and transport incentives for workers factors can be carefully considered so that workers' wages can rise significantly.

From the illustration above, the investment prospects in Maluku still have a chance to grow, but not necessarily will be in accordance with the expectations desired by the government, if the problems that possibly arise are not well anticipated. Therefore, the government should be able to create an investment climate remains conducive and stable. Figure 2. below shows us to know how far the investment in the economic empowerment group in Maluku based on the economic sectors.

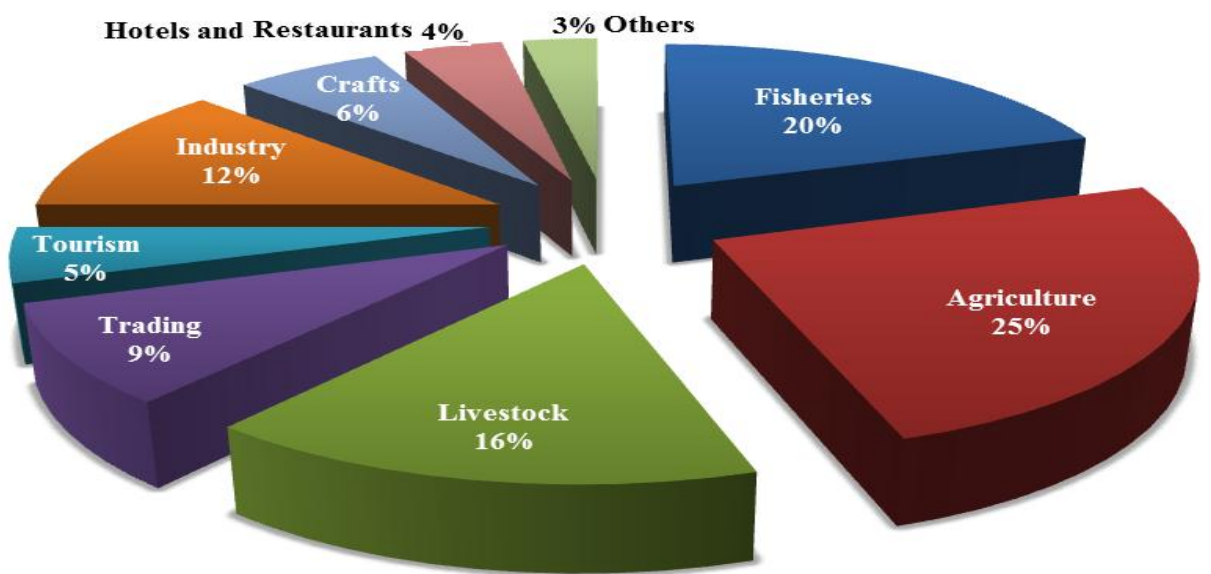

Figure 2. Total Investment by Economic Sector

Based on Figure 2. above, it can be seen that investment from empowerment of community-based economy in Maluku based on economy base sector, that industry sector $12 \%$, agriculture sector $25 \%$, hotel and restaurant $4 \%$, tourism sector $5 \%$, Handicraft sector $6 \%$, fishery $20 \%$, trade sector $9 \%$, livestock sector $16 \%$, and others $3 \%$.

From the results of this study, it can be said that the empowerment of community-based economy in Maluku in terms of investment is dominated by sectors that are considered superior such as industry, fisheries, agriculture when compared with other sectors. This indicates that these sectors in terms of infrastructure are more readily available or available when compared to infrastructure of other sectors in Maluku.

When viewed from the potential of natural resources available in four cities / regencies in Maluku, they have sufficient natural resources available to invest, yet being in opposition with the reality which is due to the limited availability of infrastructure in these areas. 


\section{Empowerment Model}

The magnitude of the potential of the industrial, fisheries, agriculture and livestock sectors, both from the availability of land and the readiness of the community in managing the microcosm at the location of the study is a matter that needs to obtain the attention of the central and local governments and other relevant parties to utilize the existing potential through efforts of empowering the communities by addressing local potentials appropriately. If this can be done, at least it will be the first step of community empowerment.

Community development seems shackled and difficult to do if the infrastructure is not first prepared or built. Through the empowerment and economic development of the community, the community is expected to develop and advance, resulting in a double effect that encourages the central and provincial governments to immediately build supporting infrastructure.

To improve the role of empowerment of Economic Institutions in utilizing the potential of the region as the findings of this study, it is necessary to make a model of increasing the role of Economic Institution for the empowerment of local potential. The modeling should be dynamic and protect the interests of farmers as producers or commodities producers. Therefore, economic institutions need to be strengthened starting from group empowerment to institutional formation of koperasi as a container or business institution where they can manage the business adequately. Therefore, this model is designed to be used or operationalized in other areas or places as far as basic and technical requirements in accordance with the findings of the review sites can be met.

The rationale of this modeling model lays at the characteristics of the development of Institutional Economy along with the support of related institutions / builders in community empowerment. The things that underlie the preparation of the model include:

a. Model is a process that must be done in an effort to empower Economic Institution

b. Model is a reference for the parties involved in the empowerment of Institutional Economics

c. Model is made primarily to protect the interests of Micro and Small Businesses that have always been on the disadvantaged side (earning the smallest value).

d. The model should provide a reasonable and measurable benefit for the Institutional Economy to take a role in empowering local potential / local superior,

e. The design and application of user-centered-design model in this case is Institutional Economy.

Taking into account of the things mentioned above, it is proposed to establish "LEMBAGA MAHIAKARYA", namely Institute of Community-Based Economic Empowerment and Development (L2PEBK), in which, in addition, it can also provide supervision assistance. This forum was established to bridge the existing business groups in each sub-district with CAPITAL, BUSINESS PARTNER, and MARKET.

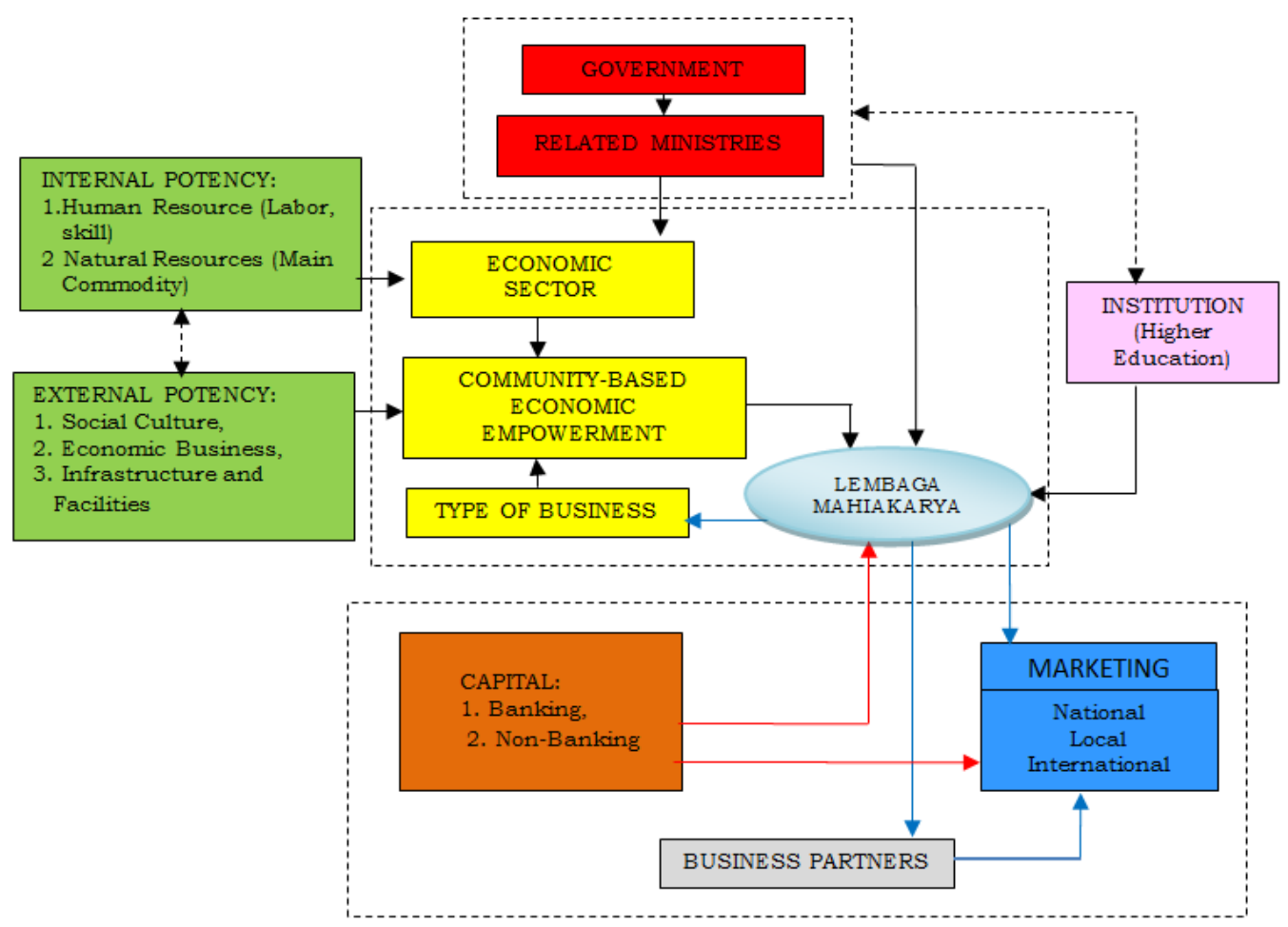

Figure 3. Design of the Model of Empowerment and Economic Development 
Conclusion:

\section{Conclusion and Suggestion}

1. In general, it can be said that empowerment will be successful if supported by several factors: (1) revolving capital assistance; (2) development assistance of facilities / infrastructure; (3) development of local institutions; (4) strengthening and development of business partnerships; and (5) facilitation of counselors.

2. No financial support and assistance from government / NGO / BUMN / Banking / other institutions. There is suspicion of a government program being run. Fear of failing in running a business. Not open to new ideas and technological developments. There is no motivation to seek opportunities for business development.

3. The effectiveness of community economic empowerment is not optimal yet, so it still needs to be improved. This can be seen from the results of the study where many community economic programs that are less suitable to the needs of the community, overlapping aid, and not sustainable.

4. The main potential economic sector to develop is fisheries. In addition to the local potential that is owned by the characteristics of the region, this sector will encourage other business sectors to grow. If the fishery sector can run sustainably, there will be other sectors of fishery supporting business such as seaweed processing industry that will have an impact on the demand of products characterized by typical food from Maluku.

5. Empowerment and development of economic institutions are expected to develop and advance so that later can have a positive impact and have multiple effects. To that end, the role of Institutional Economics needs to be designed in a model for the Development and Strengthening of Community-Based Economic Institutions.

\section{Suggestions:}

1. Distribution of revolving capital and assistance for: (a) savings and loan units; (b) and working capital to support community enterprises in various real sectors, especially joint business group (KUBE). Distribution of funds, in accordance with the stages of program implementation, is conducted directly by managers of joint business groups through a designated Bank after approval is given by the Fostering Team on the proposed regional technical team.

2. Supporting facilities and infrastructure need to continue to get attention from local and central government. Such as the availability of facilities supporting activities in the form of equipment assistance, market availability, availability of roads and sea transportation so that products arrive in the market.

3. To be able to improve the effectiveness of economic empowerment of society either from assistance in the form of technical guidance, capital, aid of production equipment and so on, need to start with data of business actors. This can be done in cooperation by the parties related to the Office of Koperasi \& SMEs as well as the Department of Industry and Commerce so that it will not happen again the program given is not in accordance with the needs of the community, and no longer happen there are community beneficiaries who are double funding.

4. To be able to take advantage of existing potential business, it should start from the leading sector that characterized regionalism especially marine fishery sector. To maintain the sustainability of this sector, the Fisheries Department needs to improve its activities both independently and in cooperation with other agencies and the wider community. In addition, other agencies may support the continuity of this sector in accordance with their respective fields.

5. To further strengthen the empowerment and development of community-based economic institutions, the design of an economic institutional model as a comprehensive recommendation based on the results of the study.

Books:

\section{References}

[1] Almasdi Syahza., 2003. Paradigma Baru: Pemasaran Produk Pertanian Berbasis Agribisnis diDaerah Riau, dalam Jurnal Ekonomi, Th. VIII/02/Juli/2003, PPD\&I Fakultas EkonomiUniversitas Tarumanagara, Jakarta.Collins, Frank. 1978. "The Interaction of Budget Characteristics and Personality Variabels with Budgetary Response Attitudes". The Accounting Review. Vol.LIII, No.2, April. pp.324-335.

[2] Azis, H. Moh. Ali, 2005, Pendekatan Sosio-Kultural dalam Pemberdayaan Masyarakat, dalam Rr. Suhartini, dkk. (eds). ModelModel Pemberdayaan Masyarakat, Yogyakarta, Pustaka Pesantren.

[3] BPS., 2015. Kota Ambon Dalam Angka. Penerbit Badan Pusat Statistik Kota Ambon. 2015.

[4] BPS., 2015. Maluku Dalam Angka. Penerbit Badan Pusat Statistik Provinsi Maluku. 2015.

[5] BPS., 2015. Maluku Tengah Dalam Angka. Penerbit Badan Pusat Statistik Kabupaten Maluku Tengah. 2015.

[6] Ekspor 50 Komoditi Utama Menurut Kawasan Barat \& Timur Indonesia Periode : 1996-2001.

[7] Hall, Hill. "Ekonomi Indonesia", Jakarta : Murai Kencana, 2001.

[8] Ife J, Tesoriero F. 2008. Alternatif pengembangan masyarakat di era globalisasi community development. Yogyakarta [ID]:Pustaka Pelajar.

[9] Krisna Wijaya. “Analisis Pemberdayaan Usaha Kecil”, Jakarta : Pustaka Wirausaha Muda, 2002. 
[10] Lembaga Penelitian Universitas Lambung Mangkuran. Kajian Pengembangan Industri Kerakyatan. 2012.

[11] Mardikanto T. 2010. Konsep-konsep pemberdayaan masyarakat. Surakarta [ID]: UNS Press.

[12] Mubyarto, (2002).Peran Ilmu Ekonomi dalam Pemberdayaan Ekonomi Rakyat, Jurnal Ekonomi dan Bisnis Indonesia, Vol 17, No.3, 233-242.

[13] North D.C. 1995.The New Institutional Economics and Third World Development. In:Harris J, Hunter J and Lewis C. (eds.). 1995. The New Institutional Economics and Third World Development. 17-26, Routledge, London.

[14] Ostrom E. 1985. Formulating the elements of institutional analysis. Paper presented to Conference on Institutional Analysis and Development. Washington D.C. May 21-22 1985.

[15] Panayatou, T. 1992. Management Concepts for Small-scale Fisheries: Economic and Social Aspects. FAO Fish. Tech. Paper, 228: 53.

[16] Pemberdayaan Ekonomi Rakyat, Syarif Hidayat \& Darwin Syamsul Bahri.

[17] Pemprov Maluku, 2011. Master Plan dan Action Plan Maluku Sebagai Lumbung Ikan Nasional, 2011 - 2015. Pemerintah Provinsi Maluku, Ambon

[18] Pendekatan Sektor Basis dan Analisisi Inpu-Output. Jurnal Ekonomi dan Studi Pembangunan Volume 10, Nomor 1:13-33.

[19] Porter, Michael E. "Competitive Strategy", Free Press, 1980.

[20] Porter, Michael E. "Competitive Advantage of Nations", Free Press, 1990.

[21] Profil Buru Selatan, Penerbit BAPPEDA dan LITBANG Kabupaten Buru Selatan Provinsi Maluku. 2014.

[22] Profil Daerah Kabupaten Maluku Tenggara, Pemerintah Kabupaten Maluku Tenggara, Badan Perencanaan Pembangunan Daerah. 2013.

[23] Rencana Induk Pengembangan Industri Kecil Menengah 2002-2004, "Buku I Kebijakan dan Strategi Umum Pengembangan, Industri Kecil Menengah", Deperindag, 2002.

[24] Subanti, S, Arif Hakim. 2009. Ekonomi Regional Provinsi Sulawesi Tenggara.

[25] Sumodiningrat G. 1999. Pemberdayaan masyarakat dan jaringan pengaman sosial. Jakarta [ID]: Gramedia Pustaka Utama.

[26] Wrihatnolo, Randy R \& Riant Nugroho Dwidjowijoto. 2007. Manajemen Pemberdayaan. Sebuah Pengantar dan Panduan untuk Pemberdayaan Masyarakat. Elex Media. Jakarta.

Gerrit M. Pentury. "Community-Based Economics Empowerment and Development in Maluku Province." IOSR Journal of Economics and Finance (IOSR-JEF) 8.4 (2017): 33-40. 